\title{
RAILROAD ACCIDENT AT BURLINGTON IN 1855
}

\author{
BY DONALD A. SINCLAIR
}

THE newspapers and pamphlets from which this article is drawn are all to be found in the Rutgers Library, and several of them are not known to be elsewhere. Mr. Sinclair, of the Class of 1938 , at present Curator of New Jerseyana, has been employed in the Rutgers Library, except for three years of army service, ever since his freshman year of college.

$7 \mathrm{EW}$ persons riding today in the coaches of the Pennsylvania 4 Railroad between New York and Philadelphia are aware of 1. the significance which that stretch of track once had for the people of New Jersey. The larger part of it, extending southward from New Brunswick, was controlled and operated until some eighty years ago by the Camden and Amboy Railroad and Transportation Company.* One of the pioneer railroads of the United States, it was chartered by the New Jersey legislature in I 830, at a time when the advantages of rail and steam transportation had been little tried and were generously doubted in many quarters. That the railroad, should it succeed, would contribute largely to the economic development of the state, was clear; consequently, the legislature undertook to foster and protect the enterprise until it had become securely established. By its original charter and by subsequent enactments, the Camden and Amboy received not only the exclusive right of rail transportation between New York and Philadelphia, but also exemption from taxation, in place of which a transit duty was levied on passengers and freight carried across the state.

The company succeeded and prospered. A year after its organization, it combined with the Delaware and Raritan Canal Company, and the two were thenceforth known commonly as the Joint Companies. In a few years the Camden and Amboy was not only operat-

\footnotetext{
* Because of its importance and controversial position, the Camden and Amboy company was the subject of numerous pamphlets and articles, a considerable proportion of which may be found in Rutgers Library. Most of the library's holdings are recorded in D. R. Stephenson, comp., The Camden and Amboy Railroad and Transportation Company; a Bibliography (Washington, D.C., 1947), published by the Bureau of Railroad Economics Library.
} 
ing the road originally authorized between South Amboy and Camden, but securing rail facilities in Pennsylvania and a bridge at Trenton, had built an additional line from the latter place to New Brunswick. Finally, an agreement with the New Jersey Railroad and Transportation Company, whose route extended northward from New Brunswick, completed the rail connection between Philadelphia and New York.

Having built a lucrative enterprise upon the favor and protection of the state, the managers of the railroad undertook to secure and improve its position. Under the shrewd leadership of Robert F. Stockton, the company strengthened its growing influence by every sort of political machination, until finally it had become a dominating force in New Jersey affairs. ${ }^{1}$

Although its influence in New Jersey was exceedingly potent, the sometimes high-handed business and political manipulations of the Camden and Amboy company did not pass unchallenged. In fact, "the Monopoly" sustained a perennial fire of criticism, much of it from Pennsylvania and New York, whose citizens felt themselves victimized by the transit duties imposed in New Jersey.

One source of popular complaint was the number of accidents, some of them fatal, which occurred on the Camden and Amboy road. In particular, the fact that several were collisions had focused public attention on the inadequacy of a single-track railroad. ${ }^{2}$ The company seemed to regard the accidents as inevitable, and, despite large annual profits and the heavy traffic which passed over its lines, gave little serious consideration to the demands for double-tracking. In I 854 , when the question of extending the term of its charter was before the legislature, the company agreed, by way of concession, to build a double track. ${ }^{3}$ Although the bill was passed, the double track was not yet a reality by the fall of 1855 .

${ }^{1}$ For a full account of the Camden and Amboy Railroad, see W. J. Lane, From Indian Trail to Iron Horse (Princeton, N.J., I939), pp. $28 \mathrm{Iff}$; the story of its early political operations is told in R. T. Thompson, "Transportation Combines and Pressure Politics in New Jersey, 1833-1836," Proc. of the N.J. Hist. Soc., LVII (1939), I-15, $71-87$.

${ }^{2}$ Lane, op. cit., pp. 301-02; Annual Reports of Railroad and Canal Companies (Trenton, N.J., I 854 ), p. 8; [Cortlandt Van Rensselaer] The Late Camden and Amboy Accident ... (Burlington, N.J., 1855), p. 4.

${ }^{3}$ R. F. Stockton, Answer. . . in Behalf of the Joint Board of the D. \& R. Canal and

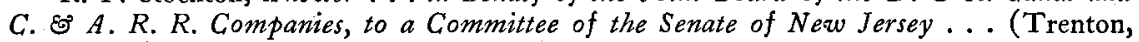
N.J., 1854 ), pp. I 6-17. 
At I0:00 o'clock on the morning of August 29, i 855, the regular train for New York left Philadelphia on schedule and less than an hour later was waiting at the Burlington station. Here the eight o'clock express from New York, traveling in an opposite direction on the same track, was expected to pass en route to Philadelphia. Learning that the express was behind schedule and still some twenty minutes distant, the conductor nevertheless held his train at Burlington only ten minutes beyond its usual time of departure, in accordance with company regulations, and then at I I:O2 pushed on. Within three miles the New York train was sighted, and both halted at once. In order to clear the track for the latter, the Philadelphia train reversed and commenced backing in the direction from which it had come, the nearest turn-out being nearly two miles behind.

It was a moderately windy day and the dust, rising in clouds from the track bed, rendered proper observation by the brakemen and conductor difficult. As the moving train neared Burlington, suddenly a two-horse carriage was seen speeding toward the crossing directly in advance of the backing cars. In an instant the rear car, striking both horses, had been derailed, but the engineer, unaware of what had happened, continued backing his train. After rolling along the embankment for nearly three hundred yards, the lead car, followed by three others, swerved and plunged into the adjacent ditch. Crashing heavily one upon the other, the four wooden coaches were virtually demolished. ${ }^{4}$

At once a crowd, drawn from Burlington and from nearby farms, began to gather at the scene. With the help of some uninjured passengers, they worked furiously to clear the dead and wounded from the wreckage. Burlington doctors were soon reinforced by contingents of their colleagues from as far away as Philadelphia, and in the hours that followed, all possible facilities were mustered for the care of the survivors. A special train, dispatched from Mount Holly, carried the injured into Burlington, ${ }^{5}$ where homes and public

${ }^{4}$ Hear Both Sides. Documents and Papers Relating to the Late Camden and Amboy Railroad Accident . . and the Correspondence between Commodore R. F. Stockton and C. Van Rensselaer (Philadelphia, I855), pp. 3-4; New-Jersey Mirror, Mount Holly, N.J., Sept. 6, I855; New York Herald, Aug. 30-31, 1855. A diagram of the crossing is in Report of the Executive Committee of the Delaware and Raritan Canal and the Camden and Amboy Railroad and Transportation Companies, on the Accident (Trenton, 1855 ).

${ }_{5}^{5}$ Mirror, Sept. 6, 1855 . 


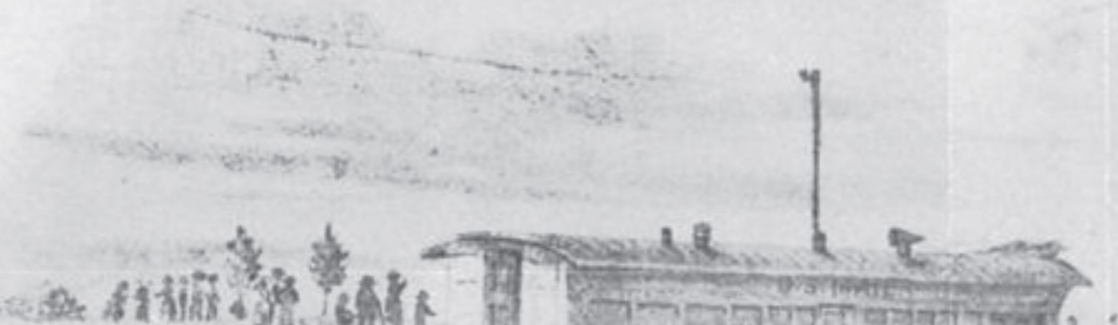

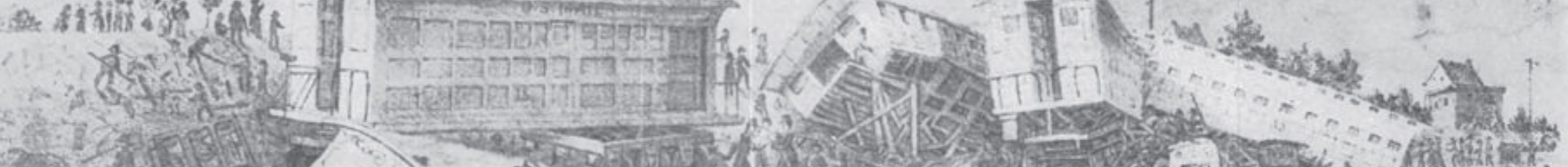

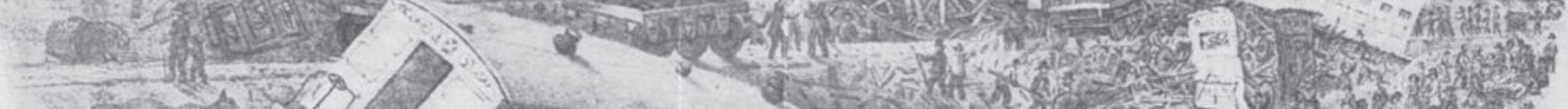

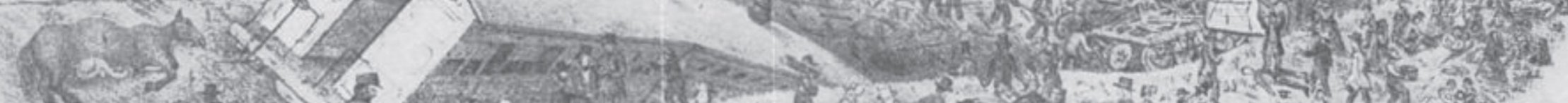

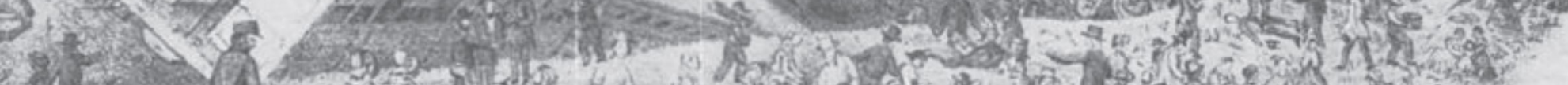

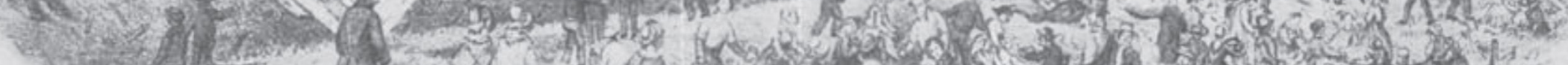

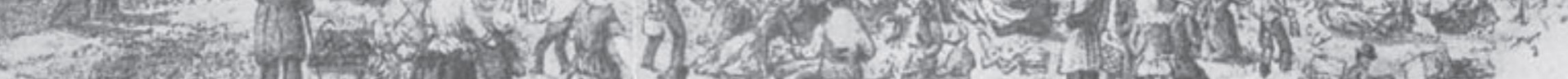

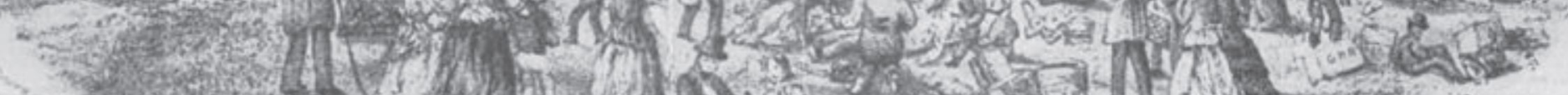

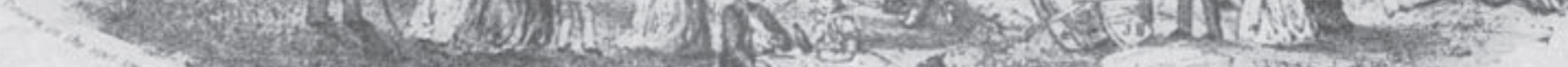

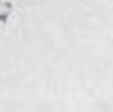

ACCIDENT ON THE CAMDEN AND AMBOY RAIL ROAD, TEA BURLINGTON, א.J.

AIT, $29 \%$ 1055 
buildings were open to receive them. The dead, resting in coffins provided by the local authorities, were placed together in the town hall. ${ }^{6}$

The total of dead, including those who succumbed during the succeeding days from effects of the accident, amounted to twenty-four, while the number of injured was reported in figures varying between sixty-five and one hundred. ${ }^{7}$ Dr. Heineken, driver of the carriage (who later insisted that he had not seen or heard the train until it was too late to halt the carriage), escaped virtually unscratched. It was a serious accident-the worst railroad disaster which had occurred in the state ${ }^{8}$ - and the important question of responsibility was yet to be fixed. A coroner's jury of nineteen men, formed several hours after the crash, began its investigation the same day. For a week, dozens of witnesses were examined and all available evidence was weighed, while an increasingly vocal public looked on. That the jury was not more strongly influenced by outside pressures is astonishing, particularly in view of the irregular qualities in its make-up. The man who served as foreman, for example, happened also to have been a passenger on the wrecked train. Moreover, on the fourth day of the investigation a juror suddenly arose and announced belligerently that one of his associates was a stockholder of the Camden and Amboy company. Upon inquiry among the jurors, a gentleman named Miller admitted himself to be the person in question, but stoutly denied that the possession of a few shares of stock could influence his judgment. After a brief discussion of this point, the other members voted in favor of Mr. Miller's retention and hastily passed on to less personal issues. ${ }^{\circ}$

Delayed by disagreements among the jurors, ${ }^{10}$ the coroner's verdict was finally released on September 5. It was a carefully worded document, ${ }^{11}$ in which the elderly driver of the carriage, the employees of the railroad, and the company itself, were charged with blame. "One of the immediate causes," it reported, "was the carelessness and recklessness of John F. D. Heineken." Quantitatively, however, the main weight of censure fell on the railroad: The forward brakeman was "censorable"; the speed of the backing train had been

${ }^{6}$ Hear Both Sides, p. 3. ${ }^{7}$ Annual Reports of Railroad and Canal Companies, 1856.

${ }^{8}$ Mirror, Sept. 6, I8 $55 . \quad{ }^{9}$ Herald, Sept. 3, $1855 . \quad{ }^{10}$ Mirror, Sept. 6, 1855.

11 The full text is given in Hear Both Sides, pp. 4-5; it also appeared in many newspapers, e.g. New Brunswicker, Sept. 6, 1855 . 
"unsafe and imprudent"; and, despite the contradictory testimony of witnesses on this point, it was asserted that the engineer in approaching the crossing "did not observe the rules of the ... Railroad ... and the laws of the State of New Jersey, in reference to the blowing of the steam-whistle on the engine." In addition, the report criticized the rules of the railroad which permitted a train to leave a station "when it is known by the Conductor thereof that an opposing Express train is on the road from the next station."

And the Jurors ... do further say, that by the "Running Regulations," issued by the said Camden and Amboy Railroad and Transportation Company, the possibility and probability of collision between opposing trains on a single track is so great, as to prove that some efficient means should be adopted to prevent the recurrence of the cause which has called this Inquest together, and that the safety of the passengers in life and limb, is of more importance than the saving of a few minutes of time.

Three jurors refused to sign the verdict, one of them being Mr. Miller, the man with the stock.

For several weeks the entire press carried the story of the accident in detail, devoting much space to its more pathetic and shocking aspects. On the question of blame, however, the newspapers of New Jersey, no doubt mindful of the Camden and Amboy company's influence in the state, maintained a cautious reserve. On the day following the accident, the editor of the New Brunswick Daily News decided, even before accurate accounts were available, that it had been caused more "by the inadvertance of Dr. Hannegan [sic] in driving upon the track without due precaution than from any neglect of duty upon the part of the engineer or conductor." The Mount Holly Mirror, published not far from Burlington, also condemned Dr. Heineken's carelessness; but, in addition, it strongly urged the need for a double track, describing the lack of it as "entirely inexcusable ... For this neglect the company is responsible, and it enters very largely into the causes of the present disaster." ${ }^{12}$ Most papers were less courageous, and contented themselves with a few words of censure for the doctor.

In contrast to those of New Jersey, the editors of New York City, ${ }^{12}$ Mirror, Sept. 6, 1855 . 
who for years had assailed the monopoly on any convenient occasion, felt no inhibitions in discussing the company's degree of responsibility. They damned the company not only freely but with wordy abandon. Scarcely had news of the accident become known when the New York press, led by the Herald, Times, Tribune, and Courier and Enquirer, launched a furious attack against the railroad and against the state of New Jersey for submitting to its domination. ${ }^{13}$ Editorials appeared under such headings as: "The Slaughter on the Camden and Amboy Railroad" and "The Camden and Amboy Homicide."14

A day after the accident, the Tribune was complaining of the lack of a double track. "This is owing to the corrupt monopoly system maintained by the State of New-Jersey . . . Had there been two tracks, this dreadful event would not have happened." The editorial then referred to the excessive speed of the train, the alleged failure of the conductor's bell-rope, and the need for better precautions at crossings; these facts "appear to us to show conclusively that the Camden and Amboy Company are pecuniarly [sic] responsible to the sufferers ..."15 Along these lines the Herald proceeded even farther. A long editorial of August $3 \mathrm{I}$ on "The Railway Manslaughter in Jersey" strongly blamed the managers of the company; despite its great wealth, "these miserable misers refuse to build a second track to their road, though they know the want of it jeopardizes hundreds of lives every day of the year." The editor then expressed his hope that the aggrieved parties "will lose no time in instituting actions against the company for damages. The Camden and Amboy monopoly is rich; it must be made to pay the price of blood." In subsequent editorials the Herald continued to urge that suits be instituted against the company. "The prosecution for the recovery of ... damages we regard in the nature of a public duty by the parties interested . . . It is not too much to insist that a half a million of dollars would be ... an insufficient award to the victims." ${ }^{16}$ The people and officials of New Jersey being so thoroughly corrupted by the railroad, it was advised that the suits be conducted in New York or Pennsylvania, where justice might still be had. ${ }^{17}$

${ }^{13}$ Daily News, Sept. 12, 1855 . Even the coroner's verdict was attacked as being too weak. Courier and Enquirer, Sept. 6, 1855 (a contemporary reprint of the editorial is in Rutgers Library).

${ }^{14}$ Herald, Sept. I, 7, 1855 .

${ }^{16}$ Herald, Sept. 1, 1855 .

${ }^{15}$ Quoted in New Brunswicker, Aug. 31,1855 .

${ }^{17}$ Herald, Sept. 8, I8, 1855 . 
After a few weeks of diatribe, the New York papers finally reduced their outcry to an occasional jibe at the political corruption in New Jersey, to which the New Jersey papers replied sporadically in kind.

On the day of the accident, some of the railroad directors, perhaps with visions of damage suits dancing before their eyes, rushed to the scene and made whatever arrangements they could for the welfare of the injured. ${ }^{18}$ But for nearly two weeks afterward, the Camden and Amboy company kept official silence. Meanwhile, despite the careful forebearance of the New Jersey press, there were indications that out-of-state anti-monopoly propaganda was taking effect. To the annoyance of the company, charges leveled against it by the New York newspapers were taken up and echoed in many a pulpit. $^{19}$

On September Io the Report of the Executive Committee to the Directors of the Delaware and Raritan Canal and Camden and Amboy Railroad Companies, on the Accident was released and published throughout the state. Its tone of complete self-vindication is understandable in the light of many prospective legal actions; any concessions of negligence or responsibility might have compromised the company's position. However, the condescending and unsympathetic language of the report served to irritate the public, which had not yet recovered from the horror of the catastrophe. After reviewing the circumstances of the accident and asserting the utter rectitude of all the company's rules, policies, and actions, the report ended with a petulant counter-attack against the anti-monopoly forces. A renewed storm of criticism immediately broke from the New York press, and two weeks later an anonymous pamphlet was published at Burlington: The Late Camden and Amboy Railroad Accident: A Review of the Camden and Amboy Company's Report. The author, Cortlandt Van Rensselaer, was a Presbyterian clergyman of independent means, who lived in Burlington. He marshalled in detail all the familiar

${ }^{18}$ Hear Both Sides, p. 24.

${ }^{19} \mathrm{Ibid}$; H. A. Boardman, God's Providence in Accidents. A Sermon . . . (Philadelphia, 1855 ). A sermon by Bishop Doane at Burlington on September 2, however, avoided the question of responsibility and treated the accident as an act of God (G. W. Doane, Death in the Midst of Life, Philadelphia, ${ }^{8} 8_{55}$ ). This thesis was carried even farther by a public meeting on the subject in the same city ten days later. In a curious $A d d r e s s$ to the People of Burlington (Burlington, 1855 ), prepared by the meeting, the accident was described as a divine visitation, specifically calculated to warn the sinners of Burlington. 
charges against the company of negligence and indifference, gleaned from the newspapers and from testimony before the coroner's jury. The main fountain of his wrath, however, sprang from the unfeeling character of the Executive Committee's report, in which the numerous deaths and injuries had been "passed by without a syllable of kindly notice or commiseration. Even an Indian could scarcely have been trained to such unnatural indifference." An explanation could lie only in the maxim, "Corporations have no souls."

Nettled especially by the ascription of "unnatural indifference," Commodore Stockton on October I I addressed an equally heated reply to the Philadelphia Ledger. Without deigning to answer most of the charges of company responsibility for the Burlington accident, he expressed the feeling that clergymen should confine their opinions to more spiritual affairs and leave mundane considerations to better qualified men. Van Rensselaer took up the gage, and during the next week several further compliments of the same sort were exchanged by the two men. ${ }^{20}$

By the end of September, interest in the Burlington accident had subsided, and the newspapers began their annual drum-beating preparatory to the November election. In the political campaign which followed, the monopoly issue, strangely enough, played virtually no part (as it had in previous years), despite the furor raised by the accident in August. Nevertheless, the Camden and Amboy company set about mending its fences, by means of improved safety measures. A considerable number of claims, in consequence of the accident, had materialized; ${ }^{21}$ moreover, the engineer of the train wrecked at Burlington was awaiting trial, under indictment for manslaughter. ${ }^{22}$ About the end of September the company adopted a better whistle for its locomotives and a sort of cow-catcher (humorously referred to as a "Heineken Catcher"), attached to the rear car of each train. ${ }^{23}$ And in December it released a new set of running regulations embodying remedies for most of the complaints raised against the com-

${ }^{20}$ Hear Both Sides, pp. 23-30.

21 The company appears to have succeeded eventually in compromising most of the claims, although several suits for large amounts were reported pending from time to time. New Brunswicker, Sept. 11; Herald, Sept. 1 0, 21, 22; Daily News, Sept. 14, 22 ; Fredonian, Sept. 12, 19, 1855 .

${ }^{22}$ Herald, Sept. 25, 1855 . He was tried in December and acquitted. Mirror, Jan. 3, Io, $\times 856$.

${ }^{23}$ New Brunswicker, Sept. 27, 1855; Daily News, Oct. 6, 1855. 
pany's safety standards following the Burlington accident. ${ }^{24}$ Further, it had been reported in October that grading was in progress at one point in preparation for double-tracking. ${ }^{25}$ By these measures, the company had spiked the guns of any possible legislative opposition which might develop.

The governor's message of January 8, read at the opening session of the legislature, referred to the Burlington accident and suggested the desirability of some legislation to increase safety in railway travel. ${ }^{26} \mathrm{~A}$ joint committee was appointed, which in due time reported to the Senate a bill "for the security of railroad companies and the safety of railway travelers." In referring to its introduction, the legislative correspondent of the New Brunswick Fredonian ${ }^{27}$ commented: "The bill, I have reason to believe, has the sanction of the leading Railroad Corporations of the State, and will doubtless be enacted into a law." It appears, however, that the bill was not only sanctioned by the "leading Railroad Companies" but in all probability had been inspired by them. ${ }^{28}$ Most of the twenty sections which it included, provided for various minor safety regulations, some of them already generally in practice by the railroads of New Jersey. The real significance of the bill, however, lay in two sections limiting the liabilities of railroad companies in cases of injury or death. ${ }^{29} \mathrm{~A}$ determined opposition developed, since the bill, in effect, set a maximum valuation on human life of five thousand dollars per head. It was successfully attacked and delayed until the end of the session, when it died. ${ }^{30}$

The double road which was eventually built, but with little show of haste on the part of the Camden and Amboy company, was completed about the end of the Civil War. ${ }^{31}$ After many further struggles between the monopoly and its enemies, ${ }^{32}$ the Joint Companies, which included the Camden and Amboy Railroad, were leased to the Pennsylvania Railroad Company in 1871 , and a powerful force in New Jersey passed from the scene.

${ }^{24}$ Fredonian, Dec. 19, 1855 .

${ }^{26}$ Fredonian, Jan. I 6,1856 .

${ }^{28}$ Ibid., Feb. 20 , 1856.

${ }^{30}$ Fredonian, Feb. 13-20, March 19, 1856; Mirror, Feb. 14, 1856.

${ }^{31}$ Lane, op. cit., pp. 292-93; Annual Report of the State Directors of the Delaware and Raritan Canal and Camden and Amboy Railroad Companies, for . . 1863, pp. 7, I 7 ; ibid., I 864 , p. 5 .

${ }^{32}$ An interesting account of the details is given in W. E. Sackett, Modern Battles of Trenton (Trenton, N.J., 1895), pp. 19-23, 48-65. 